\title{
Transactions
}

\author{
Cite this: Dalton Trans., 2012, 41, 5401
}

www.rsc.org/dalton

PAPER

\section{Rhodium pyrazolate complexes as potential CVD precursors $\uparrow$}

\author{
Joseph H. Rivers, Lauren J. DePue Anderson, Cotton M. N. Starr and Richard A. Jones*
}

Received 20th December 2011, Accepted 9th February 2012

DOI: $10.1039 / \mathrm{c} 2 \mathrm{dt12450 \textrm {e }}$

Reaction of 3,5- $\left(\mathrm{CF}_{3}\right)_{2} \mathrm{PzLi}$ with $\left[\mathrm{Rh}(\mu-\mathrm{Cl})\left(\eta^{2}-\mathrm{C}_{2} \mathrm{H}_{4}\right)_{2}\right]_{2}$ or $\left[\mathrm{Rh}(\mu-\mathrm{Cl})\left(\mathrm{PMe}_{3}\right)_{2}\right]_{2}$ in $\mathrm{Et}_{2} \mathrm{O}$ gave the dinuclear complexes $\left[\mathrm{Rh}\left(\eta^{2}-\mathrm{C}_{2} \mathrm{H}_{4}\right)_{2}\left(\mu-3,5-\left(\mathrm{CF}_{3}\right)_{2}-\mathrm{Pz}\right)\right]_{2}(\mathbf{1})$ and $\left[\mathrm{Rh}_{2}(\mu-\mathrm{Cl})\left(\mu-3,5-\left(\mathrm{CF}_{3}\right)_{2}-\mathrm{Pz}\right)\left(\mathrm{PMe}_{3}\right)_{4}\right](\mathbf{2})$ respectively $\left(3,5-\left(\mathrm{CF}_{3}\right)_{2} \mathrm{Pz}=\right.$ bis-trifluoromethyl pyrazolate). Reaction of $\mathrm{PMe}_{3}$ with $[\mathrm{Rh}(\mathrm{COD})(\mu-3,5-$ $\left.\left.\left(\mathrm{CF}_{3}\right)_{2}-\mathrm{Pz}\right)\right]_{2}$ in toluene gave $\left[\mathrm{Rh}\left(3,5-\left(\mathrm{CF}_{3}\right)_{2}-\mathrm{Pz}\right)\left(\mathrm{PMe}_{3}\right)_{3}\right](\mathbf{3})$. Reaction of $\mathbf{1}$ and $\mathbf{3}$ in toluene $(1: 4)$ gave moderate yields of the dinuclear complex $\left[\mathrm{Rh}\left(\mathrm{PMe}_{3}\right)_{2}\left(\mu-3,5-\left(\mathrm{CF}_{3}\right)_{2}-\mathrm{Pz}\right)\right]_{2}(4)$. Reaction of 3,5-( $\left(\mathrm{CF}_{3}\right)_{2} \mathrm{PzLi}$ with $\left[\mathrm{Rh}\left(\mathrm{PMe}_{3}\right)_{4}\right] \mathrm{Cl}$ in $\mathrm{Et}_{2} \mathrm{O}$ gave the ionic complex $\left[\mathrm{Rh}\left(\mathrm{PMe}_{3}\right)_{4}\right]\left[3,5-\left(\mathrm{CF}_{3}\right)_{2}-\mathrm{Pz}\right](5)$. Two of the

complexes, $\mathbf{1}$ and $\mathbf{3}$, were studied for use as CVD precursors. Polycrystalline thin films of rhodium (fcc$\mathrm{Rh})$ and metastable-amorphous films of rhodium phosphide $\left(\mathrm{Rh}_{2} \mathrm{P}\right)$ were grown from $\mathbf{1}$ and $\mathbf{3}$ respectively at 170 and $130{ }^{\circ} \mathrm{C}, 0.3 \mathrm{mmHg}$ in a hot wall reactor using $\mathrm{Ar}$ as the carrier gas $\left(5 \mathrm{cc} \mathrm{min}{ }^{-1}\right)$. Thin films of amorphous rhodium and rhodium phosphide $\left(\mathrm{Rh}_{2} \mathrm{P}\right)$ were grown from $\mathbf{1}$ and $\mathbf{3}$ at 170 and $130{ }^{\circ} \mathrm{C}$ respectively at $0.3 \mathrm{mmHg}$ in a hot wall reactor using $\mathrm{H}_{2}$ as the carrier gas $\left(7 \mathrm{cc} \mathrm{min}^{-1}\right)$.

\section{Introduction}

The use of organometallic complexes for the CVD growth of thin films of noble metals is attractive since mild conditions can often be employed compared to other methods for deposition such as physical vapour deposition (PVD) which requires sophisticated vacuum systems and extreme inputs of heat or energy. CVD processes can also allow for the selective growth of films that have good step coverage compared with traditional techniques such as PVD. ${ }^{1-3}$ Thin films of rhodium are used as electrical contacts, ${ }^{4,5}$ reflective coatings, ${ }^{6,7}$ catalysis, ${ }^{8,9}$ and wearresistant coatings for extreme conditions. ${ }^{2,10}$ Previous studies have focused on volatile compounds which feature traditional organometallic ligands such as $\mathrm{CO}, \mathrm{C}_{2} \mathrm{H}_{4}, \mathrm{C}_{5} \mathrm{H}_{5}$, and fluorinated hydrocarbons such as trifluoroacetylacetonate and it has been shown that film quality is dependent on the precursor used. ${ }^{1,10,11}$ For example, precursors for the CVD of rhodium films include $\left[\mathrm{Rh}(\mathrm{CO})_{2}(\mathrm{acac})\right], \quad\left[\mathrm{Rh}(\mu-\mathrm{Cl})(\mathrm{CO})_{2}\right]_{2}, \quad\left[\left(\eta^{5}-\mathrm{C}_{5} \mathrm{H}_{5}\right) \mathrm{Rh}\left(\eta^{2}-\mathrm{C}_{2} \mathrm{H}_{4}\right)_{2}\right]$, $\left[\mathrm{Rh}\left(\eta^{3} \text {-allyl }\right)_{3}\right], \quad\left[\mathrm{Rh}(\mathrm{tfac})_{3}\right], \quad\left[\mathrm{Rh}_{2}(\mathrm{CO})_{8}\right]$, and $\left[\left(\eta^{5}-\mathrm{C}_{5} \mathrm{H}_{5}\right) \mathrm{Rh}-\right.$ $\left.(\mathrm{CO})_{2}\right] .{ }^{1-3,11}$ Thin films of $\mathrm{Rh}$ and $\mathrm{Rh}_{2} \mathrm{O}_{3}$ have also been grown by atomic layer deposition (ALD) using organometallic precursors and $\mathrm{O}_{2}$ as the carrier gas. ${ }^{12}$ Film properties are also dependent on substrate type and growth conditions. Impurity levels depend strongly on the precursor and carrier gas used. For example, films grown using argon as a carrier gas using $[\mathrm{Rh}$

Department of Chemistry and Biochemistry, The University of Texas at Austin, 1 University Station A15300, Austin, TX 78712-0165, USA. E-mail: rajones@mail.utexas.edu; Tel: +1 (512) 471-1706

$\dagger$ Electronic supplementary information (ESI) available experimental details of CVD experiments, XPS and XRD data. CCDC 858611-858615. For ESI and crystallographic data in CIF or other electronic format see DOI: $10.1039 / \mathrm{c} 2 \mathrm{dt} 12450 \mathrm{e}$
$\left.(\mu-\mathrm{Cl})(\mathrm{CO})_{2}\right]_{2}$ at $180{ }^{\circ} \mathrm{C}$ contain $49 \% \mathrm{Rh}, 24 \% \mathrm{C}$, and $27 \% \mathrm{O}$, while films grown under the same conditions from $\left[\mathrm{Rh}\left(\eta^{3}-\right.\right.$ allyl) $)_{3}$ ] contain $86 \% \mathrm{Rh}$ and $14 \% \mathrm{C}^{10}$

In order to explore the potential to grow films with different compositions and/or new morphologies we have investigated the use of precursors which have non-traditional ligands. New CVD precursors should ideally meet several criteria. The compounds should be volatile at low temperatures $\left(\right.$ e.g. $\left.<200{ }^{\circ} \mathrm{C}\right)$, decompose cleanly at a moderately higher temperature, and be readily prepared in high purity and in relatively high yield, especially when precious metal films are desired. ${ }^{11}$ In order to impart volatility we have focused our studies on complexes which contain $\mathrm{PMe}_{3}$, and on ligands that bear $\mathrm{CF}_{3}$ groups since they are known to give rise to volatile compounds in many cases. Several groups including our own have had success utilizing appropriately substituted pyrazolate ligands to synthesize volatile complexes for use as CVD precursors. ${ }^{13-15}$ Using this strategy, we have synthesized a series of new rhodium complexes containing bis-trifluoromethyl pyrazolate $\left(3,5-\left(\mathrm{CF}_{3}\right)_{2}-\mathrm{Pz}\right)$ and $\mathrm{PMe}_{3}$. The new compounds reported in this paper, $\left[\mathrm{Rh}\left(\eta^{2}-\mathrm{C}_{2} \mathrm{H}_{4}\right)_{2}\left(\mu-3,5-\left(\mathrm{CF}_{3}\right)_{2}-\mathrm{Pz}\right)\right]_{2} \quad$ (1), $\left[\mathrm{Rh}_{2}(\mu-\mathrm{Cl})\left(\mu-3,5-\left(\mathrm{CF}_{3}\right)_{2}-\mathrm{Pz}\right)\left(\mathrm{PMe}_{3}\right)_{4}\right] \quad$ (2), $\quad\left[\mathrm{Rh}\left(3,5-\left(\mathrm{CF}_{3}\right)_{2}-\mathrm{Pz}\right)\right.$ $\left.\left(\mathrm{PMe}_{3}\right)_{3}\right](3),\left[\mathrm{Rh}\left(\mathrm{PMe}_{3}\right)_{2}\left(\mu-3,5-\left(\mathrm{CF}_{3}\right)_{2}-\mathrm{Pz}\right)\right]_{2}(4)$ and $\left[\mathrm{Rh}\left(\mathrm{PMe}_{3}\right)_{4}\right]$ $\left[3,5-\left(\mathrm{CF}_{3}\right)_{2}-\mathrm{Pz}\right](\mathbf{5})$ were isolated in moderate to good yields, characterized spectroscopically and the solid state structures determined by single crystal X-ray diffraction studies. Preliminary thin film growth studies were performed using $\mathbf{1}$ and $\mathbf{3}$. Using Ar as a carrier gas the precursors gave polycrystalline rhodium and metastable-amorphous rhodium phosphide films respectively. However, using $\mathrm{H}_{2}$ as the carrier gas the precursors gave only amorphous rhodium and rhodium phosphide films respectively. All films were heavily contaminated with carbon although the use of $\mathrm{H}_{2}$ as the carrier gas significantly reduced the levels. 

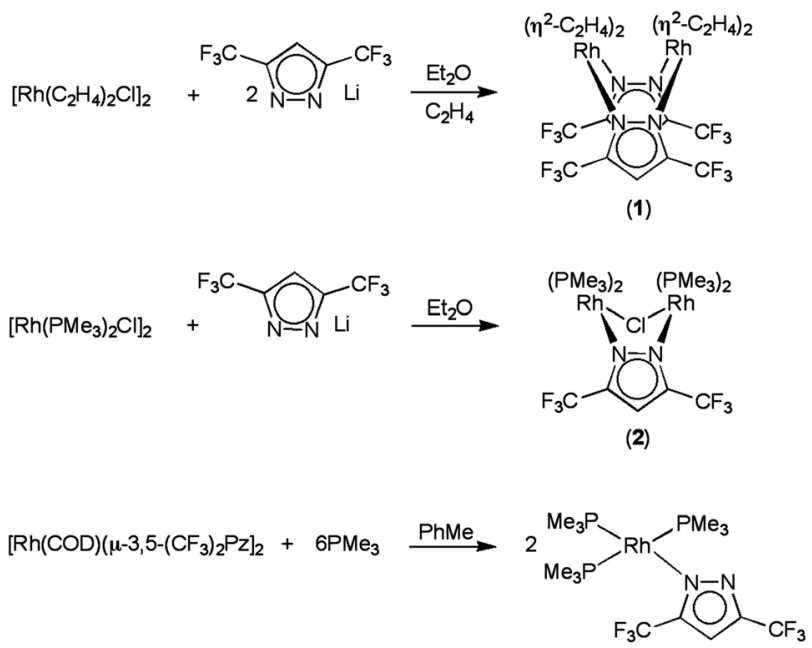

(3)

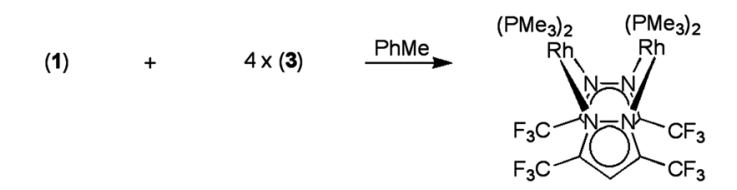

(4)

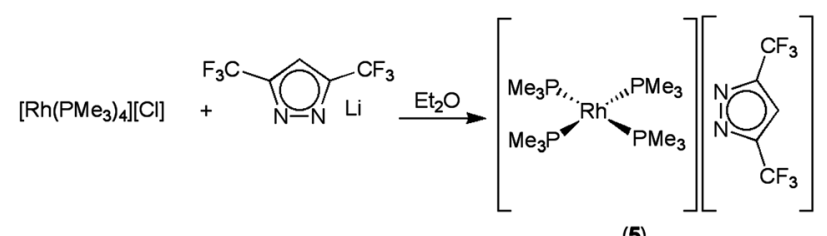

(5)

Scheme 1 Synthesis of Rh(I) pyrazolate complexes.

\section{Results and discussion}

\section{Synthesis and structures of 1-5}

$\left[\operatorname{Rh}\left(\eta^{2}-C_{2} H_{4}\right)_{2}\left(\mu-3,5-\left(C F_{3}\right)_{2}-P z\right)\right]_{2} \quad(1)$. Reaction of 3,5$\left(\mathrm{CF}_{3}\right)_{2} \mathrm{PzLi}$ with $\left[\mathrm{Rh}(\mu-\mathrm{Cl})\left(\eta^{2}-\mathrm{C}_{2} \mathrm{H}_{4}\right)_{2}\right]_{2}$ in diethyl ether at $-78{ }^{\circ} \mathrm{C}$ affords a red solution from which red crystalline $\left[\mathrm{Rh}\left(\eta^{2}-\right.\right.$ $\left.\left.\mathrm{C}_{2} \mathrm{H}_{4}\right)_{2}\left(\mu-3,5-\left(\mathrm{CF}_{3}\right)_{2}-\mathrm{Pz}\right)\right]_{2}$ (1) can be isolated in high yield (Scheme 1). Improved yields of 1 were obtained when the reaction was conducted under an atmosphere of $\mathrm{C}_{2} \mathrm{H}_{4}$. The compound crystallizes in the space group $P 2{ }_{1} / c$ with 4 molecules per unit cell. Fig. 1 shows the molecular geometry and atom numbering scheme. Key bond lengths and angles are given in Table 2. Crystallographic details for $\mathbf{1 - 5}$ are given in Table 1. The overall molecular structure of $\mathbf{1}$ is similar to those of the 3,5-dimethylpyrazolate and 3,5-dicarbomethoxypyrazolate analogs $\quad\left[\mathrm{Rh}\left(\eta^{2}-\mathrm{C}_{2} \mathrm{H}_{4}\right)_{2}\left(\mu-3,5-(\mathrm{Me})_{2} \mathrm{Pz}\right)\right]_{2}$ and $\left[\mathrm{Rh}\left(\eta^{2}-\right.\right.$ $\left.\mathrm{C}_{2} \mathrm{H}_{4}\right)_{2}\left(\mu-3,5-(\mathrm{COOMe})_{2} \mathrm{Pz}\right]_{2}$ which have been structurally characterized. ${ }^{16,17}$ Thus the $\mathrm{Rh}_{2} \mathrm{~N}_{4}$ core adopts a boat-like configuration with a dihedral angle of $93.4^{\circ}$ between pyrazolate rings while the angle between the coordination planes of the $\mathrm{Rh}$ centers is $70.8^{\circ}$. The two unique Rh centers in $\mathbf{1}$ are separated by $3.1160(10) \AA$ which is slightly longer than the distance found in $\left[\mathrm{Rh}\left(\eta^{2}-\mathrm{C}_{2} \mathrm{H}_{4}\right)_{2}\left(\mu-3,5-(\mathrm{Me})_{2} \mathrm{Pz}\right)\right]_{2}(3.0961(2) \AA)$ but shorter than that in $\left[\mathrm{Rh}\left(\eta^{2}-\mathrm{C}_{2} \mathrm{H}_{4}\right)_{2}\left(\mu-3,5-(\mathrm{COOMe})_{2} \mathrm{Pz}\right]_{2}(3.1937(6) \AA)\right.$. The average $\mathrm{Rh}-\mathrm{N}$ distance is $2.117(3) \AA$ which compares well with

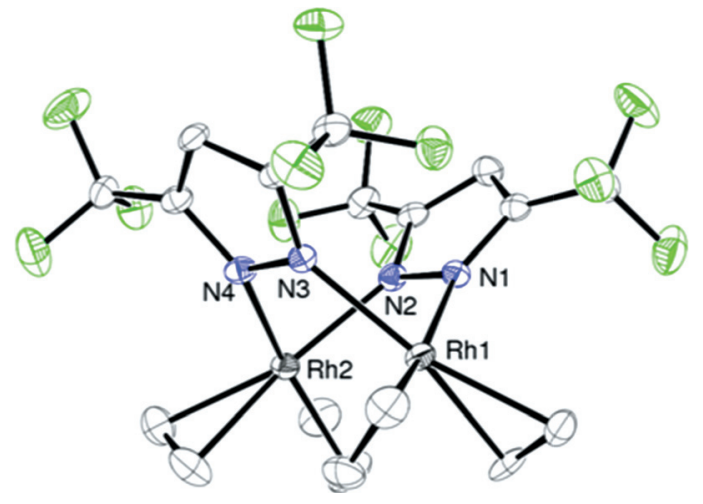

Fig. 1 Molecular structure and atom numbering scheme for $[\mathrm{Rh}(\mu-3,5-$ $\left.\left.\left(\mathrm{CF}_{3}\right)_{2} \mathrm{Pz}\right)\left(\mathrm{C}_{2} \mathrm{H}_{4}\right)_{2}\right]_{2}(\mathbf{1})$. Thermal ellipsoids are scaled to the $30 \%$ probability level. Hydrogen atoms have been omitted for clarity.

the average $\mathrm{Rh}-\mathrm{N}$ distance reported for $\mathrm{Rh}_{2}$ bridged pyrazolate complexes (2.072(2) $\AA$ ). ${ }^{18,19}$ The $\mathrm{Rh}-\mathrm{C}$ and $\mathrm{C}=\mathrm{C}$ distances of $2.140(3) \AA$ and $1.363(8) \AA$ fall within normal limits and are similar to average values in other structurally characterized $\mathrm{Rh}$ ethylene complexes (2.134(3) $\AA$ and 1.386(3) $\AA$ respectively). ${ }^{16,17}$ The ${ }^{1} \mathrm{H}$ NMR spectrum of 1 in $\mathrm{C}_{6} \mathrm{D}_{6}$ contains two multiplets at $\delta 3.22$ and 2.97 assigned to two sets of inequivalent olefinic protons. A similar pattern was observed in 1996 by Ciriano, Oro et al. ${ }^{16}$ whose analysis of variable temperature ${ }^{1} \mathrm{H}$ NMR data is consistent with the rotation of ethylene around the $\mathrm{Rh}-\mathrm{C}_{2} \mathrm{H}_{4}$ bond leading to interconversion of the trans-ethylenic protons. A single peak is observed at $-58.8 \mathrm{ppm}$ in the ${ }^{19} \mathrm{~F}$ NMR spectrum of $\mathbf{1}$.

$\left[\mathrm{Rh}_{2}(\boldsymbol{\mu}-\mathrm{Cl})\left(\boldsymbol{\mu}-\mathbf{3}, \mathbf{5}-\left(\mathrm{CF}_{3}\right)_{2}-\mathrm{Pz}\right)\left(\mathrm{PMe}_{3}\right)_{4}\right]$ (2). We have also investigated the use of other salt elimination reactions to prepare $\mathrm{Rh}$ 3,5- $\left(\mathrm{CF}_{3}\right)_{2} \mathrm{Pz}$ complexes. Thus, reaction of 3,5-( $\left.\mathrm{CF}_{3}\right)_{2} \mathrm{PzLi}$ with $\left[\mathrm{RhCl}\left(\mathrm{PMe}_{3}\right)_{2}\right]_{2}$ in diethyl ether produces the mono-pyrazolate, chloride bridged complex $\left[\mathrm{Rh}_{2}(\mu-\mathrm{Cl})\left(\mu-3,5-\left(\mathrm{CF}_{3}\right)_{2}-\mathrm{Pz}\right)\left(\mathrm{PMe}_{3}\right)_{4}\right]$ (2) which can be recrystallized from hexane at $-25^{\circ} \mathrm{C}$ as orange needles. Although there are many examples of dinuclear heterobridged $\mathrm{Rh}$ (III) complexes in the literature, there are fewer $\mathrm{Rh}_{2}(\mathrm{I})$ complexes that are bridged by both a halide and another anionic bridging ligand. Common bridging ligands in combination with halides are thiolates and phosphides as in $\left[\mathrm{Rh}_{2}(\mu-\mathrm{Cl})\right.$ $\left.\left(\mu-\mathrm{S}-\mathrm{C}_{6} \mathrm{H}_{6} \mathrm{Cl}\right)(\mathrm{CO})_{2}\left(\mathrm{P}\left({ }^{t} \mathrm{Bu}\right)_{3}\right)_{2}\right] \quad$ and $\quad\left[\mathrm{Rh}_{2}(\mu-\mathrm{Cl})\left(\mu-\mathrm{P}\left({ }^{t} \mathrm{Bu}\right)_{2}\right)\right.$ $\left.(\mathrm{COD})_{2}\right]^{20,21}$ There are even fewer halide and pyrazolate bridged dirhodium complexes. For example Trotter and coworkers isolated the chloride/pyrazolate bridged $\mathrm{Rh}_{2}$ complex, $\left[\mathrm{Rh}_{2}(\mu-\mathrm{Cl})(\mu-\mathrm{Pz})(\mathrm{CO})_{4}\right]$ which bears four CO groups. ${ }^{22}$ To our knowledge $\mathbf{2}$ is the first mixed-bridge dinuclear Rh complex that contains bis-trifluoromethyl pyrazolate and $\mathrm{PMe}_{3}$ ligands. Complex 2 crystallizes in the space group $P 2_{1} / c$ with 4 molecules per unit cell. Fig. 2 shows the overall molecular geometry and atom numbering scheme for $\mathbf{2}$ and a listing of key bond lengths and angles is given in Table 3 . The two crystallographically independent $\mathrm{Rh}$ centers have distorted square planar geometries with the central $\mathrm{Rh}_{2} \mathrm{~N}_{2} \mathrm{Cl}$ core adopting a boat-like conformation. There is more distortion from square planar geometry than that found in $\left[\mathrm{Rh}_{2}(\mu-\mathrm{Cl})(\mu-\mathrm{Pz})(\mathrm{CO})_{4}\right]$. For example the trans $\mathrm{N}-\mathrm{Rh}-$ $\mathrm{P}$ angles in $\mathbf{2}$ are $162.71(8)$ and $170.15(8)^{\circ}$ while the analogous 
Table 1 Crystallographic data for compounds 1-5

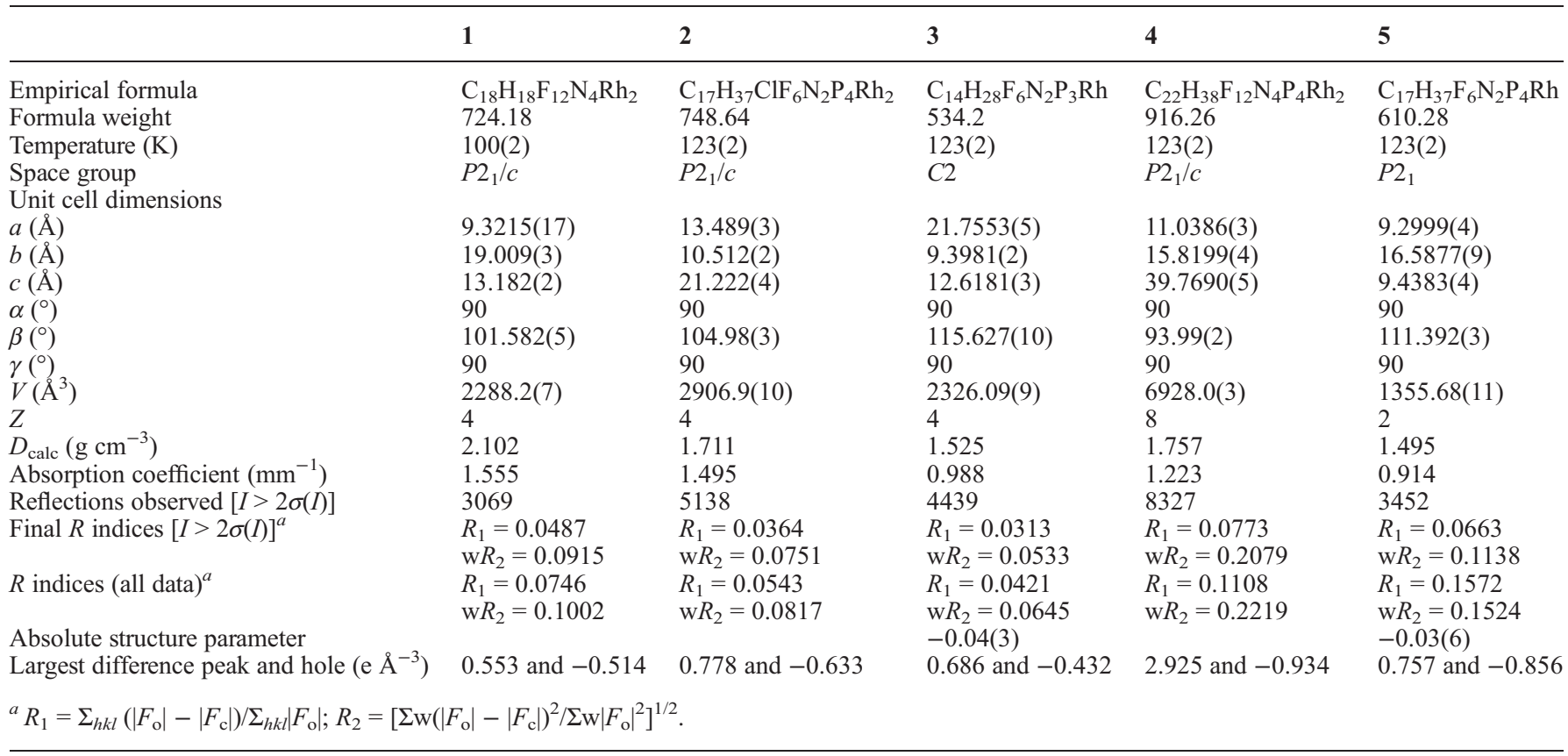

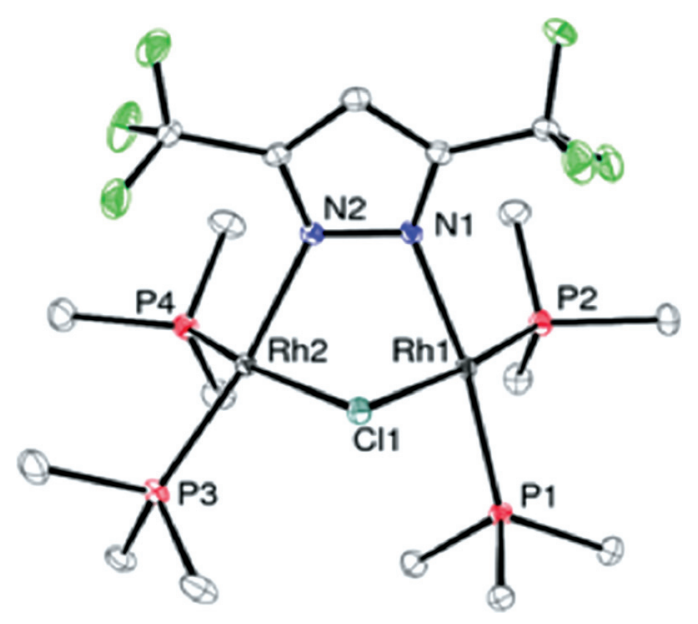

Fig. 2 Molecular structure and atom numbering scheme for $[\mathrm{Rh}(\mu-3,5-$ $\left.\left.\left(\mathrm{CF}_{3}\right)_{2} \mathrm{Pz}\right)(\mu-\mathrm{Cl})\left(\mathrm{PMe}_{3}\right)_{4}\right](2)$. Thermal ellipsoids are scaled to the $30 \%$ probability level. Hydrogen atoms have been omitted for clarity.

value in $\left[\mathrm{Rh}_{2}(\mu-\mathrm{Cl})(\mu-\mathrm{Pz})(\mathrm{CO})_{4}\right]$ is $176.0(2)^{\circ}$. In addition the carbonyl complex displays almost no bending between the edge sharing rhodium-ligand planes (angle between planes $145^{\circ}$ ) and has a Rh-Rh distance of 3.6275(9) $\AA$ whereas 2 has an angle of $100^{\circ}$ between planes and a Rh-Rh distance of 3.0503(7) $\AA$. The structural differences are consistent with computational studies by Lledos and Alvarez who postulated that the angle between planes and metal-metal distances in edge-sharing binuclear square planar $\mathrm{d}^{8}$ complexes are smaller when good $\sigma$-donor ligands are present. ${ }^{23}$ Steric interactions may also be involved as 2 contains $\mathrm{PMe}_{3}$ instead of $\mathrm{CO}$ as well as the bis $\left(\mathrm{CF}_{3}\right)$ substituted pyrazolate instead of unsubstituted $\mathrm{Pz}$ in $\left[\mathrm{Rh}_{2}(\mu-\mathrm{Cl})(\mu-\mathrm{Pz})\right.$ $(\mathrm{CO})_{4}$. Solutions of 2 in $\mathrm{C}_{6} \mathrm{D}_{6}$ are unstable and there is a slow conversion to a mixture of $\left[\mathrm{Rh}(\mu-\mathrm{Cl})\left(\mathrm{PMe}_{3}\right)_{2}\right]_{2}$ and 4 which
Table 2 Selected bond lengths $(\AA)$ and angles $\left({ }^{\circ}\right)$ for $\mathbf{1}$

\begin{tabular}{llll}
\hline Bond lengths & & & \\
\hline $\mathrm{Rh}(1)-\mathrm{N}(1)$ & $2.117(5)$ & $\mathrm{Rh}(2)-\mathrm{C}(17)$ & $2.129(7)$ \\
$\mathrm{Rh}(1)-\mathrm{N}(3)$ & $2.108(5)$ & $\mathrm{C}(11)-\mathrm{C}(12)$ & $1.371(9)$ \\
$\mathrm{Rh}(2)-\mathrm{N}(2)$ & $2.114(5)$ & $\mathrm{C}(13)-\mathrm{C}(14)$ & $1.366(10)$ \\
$\mathrm{Rh}(2)-\mathrm{N}(4)$ & $2.124(5)$ & $\mathrm{C}(15)-\mathrm{C}(16)$ & $1.371(11)$ \\
$\mathrm{Rh}(1)-\mathrm{C}(11)$ & $2.123(6)$ & $\mathrm{C}(17)-\mathrm{C}(18)$ & $1.336(10)$ \\
$\mathrm{Rh}(1)-\mathrm{C}(12)$ & $2.139(6)$ & $\mathrm{N}(3)-\mathrm{Rh}(1)-\mathrm{N}(1)$ & $83.19(18)$ \\
$\mathrm{Rh}(1)-\mathrm{C}(13)$ & $2.151(6)$ & $\mathrm{N}(2)-\mathrm{Rh}(2)-\mathrm{N}(4)$ & $82.66(19)$ \\
$\mathrm{Rh}(1)-\mathrm{C}(14)$ & $2.148(6)$ & $\mathrm{C}(11)-\mathrm{Rh}(1)-\mathrm{C}(12)$ & $37.5(2)$ \\
$\mathrm{Rh}(2)-\mathrm{C}(15)$ & $2.143(8)$ & $\mathrm{C}(14)-\mathrm{Rh}(1)-\mathrm{C}(13)$ & $37.1(3)$ \\
$\mathrm{Rh}(2)-\mathrm{C}(16)$ & $2.141(8)$ & $\mathrm{C}(15)-\mathrm{Rh}(2)-\mathrm{C}(16)$ & $37.3(3)$ \\
$\mathrm{Rh}(2)-\mathrm{C}(18)$ & $2.138(7)$ & $\mathrm{C}(17)-\mathrm{Rh}(2)-\mathrm{C}(18)$ & $36.5(3)$ \\
\end{tabular}

Table 3 Selected bond lengths $(\AA)$ and angles $\left({ }^{\circ}\right)$ for $\mathbf{2}$

\begin{tabular}{lllr}
\hline Bond lengths & \multicolumn{3}{l}{ Bond angles } \\
\hline $\mathrm{Rh}(1)-\mathrm{N}(1)$ & $2.132(3)$ & $\mathrm{N}(1)-\mathrm{Rh}(1)-\mathrm{P}(2)$ & $95.45(8)$ \\
$\mathrm{Rh}(2)-\mathrm{N}(2)$ & $2.120(3)$ & $\mathrm{N}(1)-\mathrm{Rh}(1)-\mathrm{P}(1)$ & $170.15(8)$ \\
$\mathrm{Rh}(1)-\mathrm{Cl}(1)$ & $2.4513(10)$ & $\mathrm{P}(2)-\mathrm{Rh}(1)-\mathrm{P}(1)$ & $93.54(4)$ \\
$\mathrm{Rh}(2)-\mathrm{Cl}(1)$ & $2.4428(12)$ & $\mathrm{N}(1)-\mathrm{Rh}(1)-\mathrm{Cl}(1)$ & $80.04(8)$ \\
$\mathrm{Rh}(1)-\mathrm{P}(1)$ & $2.2252(10)$ & $\mathrm{P}(2)-\mathrm{Rh}(1)-\mathrm{Cl}(1)$ & $174.15(3)$ \\
$\mathrm{Rh}(1)-\mathrm{P}(2)$ & $2.1907(10)$ & $\mathrm{P}(1)-\mathrm{Rh}(1)-\mathrm{Cl}(1)$ & $90.72(3)$ \\
$\mathrm{Rh}(2)-\mathrm{P}(3)$ & $2.2155(10)$ & $\mathrm{N}(2)-\mathrm{Rh}(2)-\mathrm{P}(4)$ & $95.25(8)$ \\
$\mathrm{Rh}(2)-\mathrm{P}(4)$ & $2.1846(12)$ & $\mathrm{N}(2)-\mathrm{Rh}(2)-\mathrm{P}(3)$ & $162.71(8)$ \\
$\mathrm{P}(4)-\mathrm{Rh}(2)-\mathrm{Cl}(1)$ & $165.85(3)$ & $\mathrm{P}(4)-\mathrm{Rh}(2)-\mathrm{P}(3)$ & $94.37(4)$ \\
$\mathrm{P}(3)-\mathrm{Rh}(2)-\mathrm{Cl}(1)$ & $93.27(4)$ & $\mathrm{N}(2)-\mathrm{Rh}(2)-\mathrm{Cl}(1)$ & $80.53(8)$ \\
\hline
\end{tabular}

takes place over several days. Thus the ${ }^{31} \mathrm{P}-\mathrm{NMR}$ spectra of fresh solutions of 2 in $\mathrm{C}_{6} \mathrm{D}_{6}$ at room temperature exhibit a complex pattern suggesting a dynamic system involving dissociation of the dinuclear complex in solution. The spectrum consists of four doublets, two of which exhibit Rh-P coupling $(J=167 \mathrm{~Hz})$ while the other two signals are doublets of quartets with both $\mathrm{Rh}-\mathrm{P}$ and $\mathrm{F}-\mathrm{P}$ coupling $(J=204$ and $4 \mathrm{~Hz}$ respectively). The 


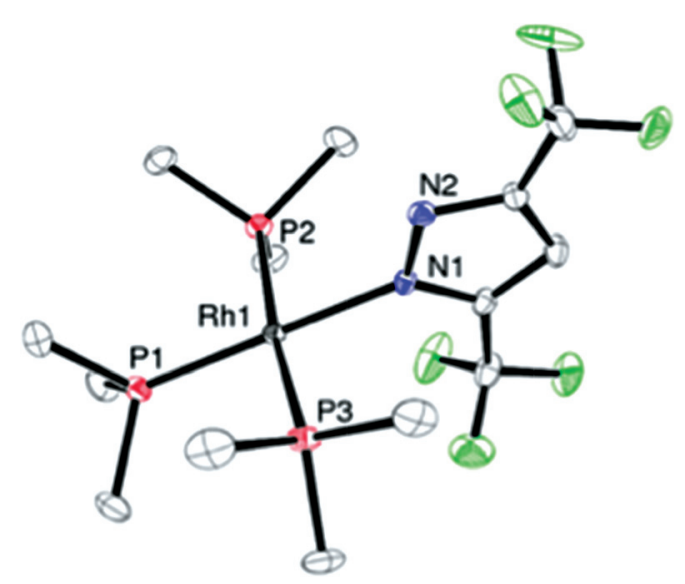

Fig. 3 Molecular structure and atom numbering scheme for $[\mathrm{Rh}(3,5-$ $\left.\left.\left(\mathrm{CF}_{3}\right)_{2}-\mathrm{Pz}\right)\left(\mathrm{PMe}_{3}\right)_{3}\right](3)$. Thermal ellipsoids are scaled to the $30 \%$ probability level. Hydrogen atoms have been omitted for clarity.

${ }^{19} \mathrm{~F}$ NMR consists of a doublet $\left(J_{\mathrm{P}-\mathrm{F}}=4 \mathrm{~Hz}\right)$. After several days at room temperature the solution changes from bright orange to dark yellow and ${ }^{31} \mathrm{P}$ and ${ }^{19} \mathrm{~F}$ NMR spectra reveal the presence of $\left[\mathrm{Rh}(\mu-\mathrm{Cl})\left(\mathrm{PMe}_{3}\right)_{2}\right]_{2}$ and $4 .^{22}$ Complex 4 can be isolated from these solutions by cooling aged toluene solutions of $\mathbf{2}$ to $-25^{\circ} \mathrm{C}$.

[Rh(3,5-(CF $\left.\left.)_{2}-\mathrm{Pz}\right)\left(\mathrm{PMe}_{3}\right)_{3}\right]$ (3). Treatment of a toluene solution of $\left[\mathrm{Rh}_{2}\left(\mu-3,5-\left(\mathrm{CF}_{3}\right)_{2}-\mathrm{Pz}\right)(\mathrm{COD})\right]_{2}$ with six equivalents of $\mathrm{PMe}_{3}$ at room temperature affords the neutral monomeric complex $\mathrm{Rh}\left(3,5-\left(\mathrm{CF}_{3}\right)_{2}-\mathrm{Pz}\right)\left(\mathrm{PMe}_{3}\right)_{3}$ (3) in high yield. The complex can also be prepared by the reaction of $\mathrm{Rh}\left(\mathrm{PMe}_{3}\right)_{3} \mathrm{Cl}$ with $3,5-\left(\mathrm{CF}_{3}\right)_{2}-\mathrm{PzLi}$ and is readily recrystallized from hexane at $-25^{\circ} \mathrm{C}$ as yellow needles. There are numerous examples of $\mathrm{Rh}(\mathrm{I})$ complexes of the type $\mathrm{Rh}\left(\mathrm{PR}_{3}\right)_{3} \mathrm{X}$, but somewhat surprisingly, to the best of our knowledge, this is the first pyrazolate complex of this kind. The compound crystallizes in the space group $C 2$ with four molecules per unit cell. Fig. 3 shows the overall molecular geometry and atom numbering scheme for $\mathbf{3}$ and a listing of key bond lengths and angles appears in Table 4. The $\mathrm{Rh}$ center possess nearly perfect square planar coordination with the mutually trans $\mathrm{PMe}_{3}$ groups coordinated slightly closer to the pyrazolate ligand. The pyrazolate ring is oriented perpendicular to the $\mathrm{Rh}$ coordination plane. Interestingly the molecule has near molecular mirror symmetry yet does not adopt mirror symmetry that could be imparted crystallographically. The $\mathrm{Rh}-\mathrm{P}$ bond trans to the pyrazolate is shorter $(2.228(1) \AA)$ than the mutually trans Rh-P bonds (avg. 2.3125(7) $\AA$ ) by $0.0845(12) \AA$. The same contraction in $\mathrm{Rh}-\mathrm{P}$ bonds trans to the " $\mathrm{X}$ " ligand are found in $\mathrm{Rh}\left(\mathrm{PMe}_{3}\right)_{3} \mathrm{Cl}, \mathrm{Rh}\left(\mathrm{PMe}_{3}\right)_{3}\left(\mathrm{~S}-\mathrm{C}_{6} \mathrm{H}_{5}\right)$, and $\mathrm{Rh}\left(\mathrm{PMe}_{3}\right)_{3}(\mathrm{O}-$ $p$ Tol) where the $\mathrm{Rh}-\mathrm{P}$ distance is shorter than the mutually trans $\mathrm{Rh}-\mathrm{PMe}_{3}$ distance by $0.095(1) \AA, 0.063(3) \AA$, and $0.1058(11) \AA$ respectively. ${ }^{24-26}$ This observation is likely due to the $\pi$-basic nature of these anionic ligands resulting in extra electron density available at the metal to overlap in a $\pi$ fashion with $\mathrm{PMe}_{3}$. In contrast the mutually trans $\mathrm{PMe}_{3}$ ligands compete with each other to accept electron density for $\pi$-bonding. The ${ }^{31} \mathrm{P} N M R$ spectrum of $\mathbf{3}$ contains a well resolved doublet of triplets centered at $-0.51 \mathrm{ppm}\left(J_{\mathrm{P}-\mathrm{Rh}}=154.1 \mathrm{~Hz}, J_{\mathrm{P}-\mathrm{P}}=47.3 \mathrm{~Hz}\right)$ assigned to $\mathrm{P}$ trans to pyrazolate. There is also a doublet of doublets
Table 4 Selected bond lengths $(\AA)$ and angles $\left({ }^{\circ}\right)$ for $\mathbf{3}$

\begin{tabular}{llll}
\hline Bond lengths & & Bond angles & \\
\hline $\mathrm{Rh}(1)-\mathrm{N}(1)$ & $2.096(3)$ & $\mathrm{N}(1)-\mathrm{Rh}(1)-\mathrm{P}(1)$ & $179.31(10)$ \\
$\mathrm{Rh}(1)-\mathrm{P}(1)$ & $2.2278(11)$ & $\mathrm{N}(1)-\mathrm{Rh}(1)-\mathrm{P}(2)$ & $87.33(9)$ \\
$\mathrm{Rh}(1)-\mathrm{P}(2)$ & $2.3140(11)$ & $\mathrm{N}(1)-\mathrm{Rh}(1)-\mathrm{P}(3)$ & $86.22(9)$ \\
$\mathrm{Rh}(1)-\mathrm{P}(3)$ & $2.3111(11)$ & $\mathrm{P}(1)-\mathrm{Rh}(1)-\mathrm{P}(2)$ & $92.62(4)$ \\
& & $\mathrm{P}(1)-\mathrm{Rh}(1)-\mathrm{P}(3)$ & $93.88(4)$ \\
& & $\mathrm{P}(3)-\mathrm{Rh}(1)-\mathrm{P}(2)$ & $172.62(4)$ \\
\hline
\end{tabular}

centered at $-10.21 \mathrm{ppm}\left(J_{\mathrm{P}-\mathrm{Rh}}=135.0 \mathrm{~Hz}, J_{\mathrm{P}-\mathrm{P}}=46.5 \mathrm{~Hz}\right)$. The ${ }^{19} \mathrm{~F}$ NMR spectrum contains two singlets at -58.5 and $-60.0 \mathrm{ppm}$ assigned to the two inequivalent $\mathrm{CF}_{3}$ groups. The complex is stable in solution under an inert atmosphere, but quickly decomposes in the presence of air in solution and the solid state at room temperature.

$\left[\mathrm{Rh}_{2}\left(\boldsymbol{\mu}-\mathbf{3 , 5}-\left(\mathrm{CF}_{3}\right)_{2}-\mathrm{Pz}\right)\left(\mathrm{PMe}_{3}\right)_{2}\right]_{\mathbf{2}}$ (4). During the course of this work we isolated and characterized the symmetrical tetra phosphine $\mathrm{Rh}_{2}$ bis-pyrazolate complex $\left[\mathrm{Rh}_{2}\left(\mu-3,5-\left(\mathrm{CF}_{3}\right)_{2}-\mathrm{Pz}\right)-\right.$ $\left.\left(\mathrm{PMe}_{3}\right)_{2}\right]_{2}$ (4) in low yields from a number of reactions. For example, reaction of $\left[\mathrm{Rh}(\mu-\mathrm{Cl})\left(\mathrm{PMe}_{3}\right)_{2}\right]_{2}$ with two equivalents of 3,5-( $\left(\mathrm{CF}_{3}\right)_{2} \mathrm{PzLi}$ produces low yields of a mixture of $\mathbf{2}$ and $\mathbf{4}$. As noted above $\mathbf{4}$ can also be isolated from aged solutions of $\mathbf{2}$ in toluene while reaction of $\mathbf{1}$ with excess $\mathrm{PMe}_{3}$ produces only the mononuclear complex $\mathbf{3}$. A reliable route to $\mathbf{4}$ in moderate yield (34\%) was discovered by simply combining a mixture of $\mathbf{1}$ and 3 in toluene in a 1:4 mole ratio and slowly purging the solution with a stream of $\mathrm{N}_{2}$ to remove $\mathrm{C}_{2} \mathrm{H}_{4}$. Subsequent removal of solvent and cooling $\left(-25^{\circ} \mathrm{C}\right)$ produces 3 as yellow crystals. There are many examples of bis-pyrazolate bridged $\mathrm{Rh}_{2}(\mathrm{I})$ complexes of formula $\left[\mathrm{Rh}(\mathrm{Pz}) \mathrm{L}_{2}\right]_{2}$ where $\mathrm{L}$ is a neutral ligand. Most examples contain olefinic ligands, as in $\mathbf{1},\left[\mathrm{Rh}(\mathrm{COD})_{2}(\mu-3,5-\right.$ $\left.\left.(\mathrm{Me})_{2} \mathrm{Pz}\right)\right]_{2}, \quad\left[\mathrm{Rh}\left(\eta^{2}-\mathrm{C}_{2} \mathrm{H}_{4}\right)_{2}\left(\mu-3,5-(\mathrm{Me})_{2} \mathrm{Pz}\right)\right]_{2}, \quad$ and $\left[\mathrm{Rh}\left(\eta^{2}-\right.\right.$ $\left.\left.\mathrm{C}_{2} \mathrm{H}_{4}\right)_{2}\left(\mu-3,5-(\mathrm{Me})_{2} \mathrm{Pz}\right)\right]_{2}$. Examples with carbon monoxide and isocyanides include $\left[\mathrm{Rh}\left(\mu-3,5-(\mathrm{Me})_{2}-\mathrm{Pz}\right)(\mathrm{CO})_{2}\right]_{2}, \quad[\mathrm{Rh}(\mu-\mathrm{Pz})-$ $\left.(\mathrm{CO})_{2}\right]_{2}$, and $\left[\mathrm{Rh}(\mu-\mathrm{Pz})\left(\mathrm{CNBu}^{t}\right)_{2}\right]_{2} \cdot{ }^{12,16,27}$ To the best of our knowledge 4 is the first structurally characterized bis-pyrazolate complex of this type utilizing a trialkylphosphine exclusively as the neutral ligand. Complex 4 crystallizes in the space group $P 2_{1} / c$. There are two crystallographically independent, yet chemically identical, molecules in the asymmetric unit with a total of 8 molecules per unit cell. Fig. 4 shows the overall molecular geometry and atom numbering scheme for $\mathbf{4}$ and a listing of key bond lengths and angles appears in Table 5 .

The molecular geometry of $\mathbf{4}$ is similar to that of $\mathbf{1}$ with the $\mathrm{Rh}_{2} \mathrm{~N}_{2}$ core adopting a boat-like conformation with a dihedral angle of $80.1^{\circ}$ between pyrazolate rings and the angle between the two $\mathrm{Rh}(\mathrm{I})$ coordination planes of $70.1^{\circ}$. This conformation results in a Rh-Rh distance of 3.1220(7) $\AA$ which is longer than the analogous distance found in $\mathbf{1}$, no doubt due to the relatively bulkier $\mathrm{PMe}_{3}$ ligands. The average $\mathrm{Rh}-\mathrm{N}$ distance (2.144(3) $\AA$ ) is slightly longer than the average $\mathrm{Rh}-\mathrm{N}$ distance found in bridging pyrazolate complexes $(2.072(2) \AA) .{ }^{13}$ The average $\mathrm{Rh}-\mathrm{P}$ distance $(2.2144(10) \AA)$ is also slightly longer than the average $\mathrm{Rh}-\mathrm{P}$ distance found in $\left[\mathrm{Rh}(\mu-\mathrm{Cl})\left(\mathrm{PMe}_{3}\right)_{2}\right]_{2}$ (2.1948(9) $\AA$ ). Again the steric requirements of the $\mathrm{CF}_{3}$ substituted pyrazolate and $\mathrm{PMe}_{3}$ ligands are possible causes for these slightly longer than average bond lengths. The ${ }^{31} \mathrm{P}$ NMR spectrum of $\mathbf{4}$ contains 


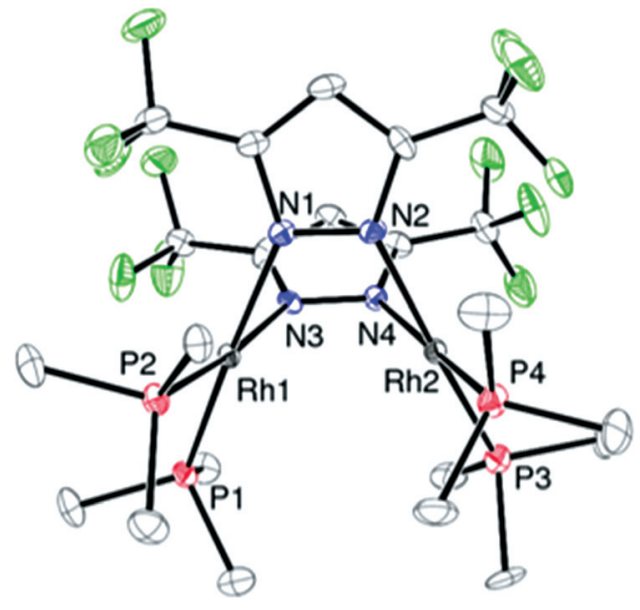

Fig. 4 Molecular structure and atom numbering scheme for one of the crystallographically independent molecules of $\left[\mathrm{Rh}\left(\mu-3,5-\left(\mathrm{CF}_{3}\right)_{2} \mathrm{Pz}\right)-\right.$ $\left.\left(\mathrm{PMe}_{3}\right)_{2}\right]_{2}$ (4). Thermal ellipsoids are scaled to the $30 \%$ probability level. Hydrogen atoms have been omitted for clarity.

Table 5 Selected bond lengths $(\AA)$ and angles $\left({ }^{\circ}\right)$ for 4

\begin{tabular}{lllc}
\hline Bond lengths & \multicolumn{3}{l}{ Bond angles } \\
\hline $\mathrm{Rh}(1)-\mathrm{N}(1)$ & $2.129(9)$ & $\mathrm{N}(3)-\mathrm{Rh}(1)-\mathrm{P}(1)$ & $93.5(2)$ \\
$\mathrm{Rh}(1)-\mathrm{N}(3)$ & $2.142(8)$ & $\mathrm{N}(1)-\mathrm{Rh}(1)-\mathrm{P}(2)$ & $93.0(2)$ \\
$\mathrm{Rh}(1)-\mathrm{P}(1)$ & $2.211(3)$ & $\mathrm{N}(3)-\mathrm{Rh}(1)-\mathrm{P}(2)$ & $173.1(2)$ \\
$\mathrm{Rh}(1)-\mathrm{P}(2)$ & $2.212(3)$ & $\mathrm{P}(1)-\mathrm{Rh}(1)-\mathrm{P}(2)$ & $92.43(12)$ \\
$\mathrm{Rh}(2)-\mathrm{N}(4)$ & $2.134(9)$ & $\mathrm{N}(4)-\mathrm{Rh}(2)-\mathrm{N}(2)$ & $80.2(3)$ \\
$\mathrm{Rh}(2)-\mathrm{N}(2)$ & $2.153(9)$ & $\mathrm{N}(4)-\mathrm{Rh}(2)-\mathrm{P}(3)$ & $93.5(2)$ \\
$\mathrm{Rh}(2)-\mathrm{P}(4)$ & $2.211(3)$ & $\mathrm{N}(2)-\mathrm{Rh}(2)-\mathrm{P}(3)$ & $172.9(3)$ \\
$\mathrm{Rh}(2)-\mathrm{P}(3)$ & $2.224(3)$ & $\mathrm{N}(4)-\mathrm{Rh}(2)-\mathrm{P}(4)$ & $172.9(3)$ \\
$\mathrm{N}(1)-\mathrm{Rh}(1)-\mathrm{N}(3)$ & $81.2(3)$ & $\mathrm{N}(2)-\mathrm{Rh}(2)-\mathrm{P}(4)$ & $92.9(3)$ \\
$\mathrm{N}(1)-\mathrm{Rh}(1)-\mathrm{P}(1)$ & $174.5(2)$ & $\mathrm{P}(4)-\mathrm{Rh}(2)-\mathrm{P}(3)$ & $93.44(13)$ \\
\hline
\end{tabular}

a doublet centered at $1.62 \mathrm{ppm}\left(J_{\mathrm{Rh}-\mathrm{P}}=172.5 \mathrm{~Hz}\right)$, and the ${ }^{19} \mathrm{~F}$ NMR spectrum contains only a singlet at $-57.97 \mathrm{ppm}$. These observations suggest that there is no dissociation of the dimer in solution.

$\left[\mathrm{Rh}_{(}\left(\mathrm{PMe}_{3}\right)_{4}\right]\left[\left(\mathbf{3 , 5}-\left(\mathrm{CF}_{3}\right)_{2}-\mathrm{Pz}\right)\right]$ (5). Reaction of $\left[\mathrm{Rh}\left(\mathrm{PMe}_{3}\right)_{4}\right]$ [Cl] with one equivalent of 3,5-( $\left(\mathrm{CF}_{3}\right)_{2}-\mathrm{PzLi}$ in diethyl ether in the presence of excess $\mathrm{PMe}_{3}$ affords the ionic compound $[\mathrm{Rh}-$ $\left.\left(\mathrm{PMe}_{3}\right)_{4}\right]\left[\left(3,5-\left(\mathrm{CF}_{3}\right)_{2}-\mathrm{Pz}\right)\right](\mathbf{5})$ in moderate yields. Cationic complexes of the type $\left[\mathrm{RhL}_{4}\right]^{+}$are known for $\mathrm{L}=\mathrm{PMe}_{3}, \mathrm{PPh}_{3}$, and $\mathrm{P}(\mathrm{OR})_{3}$ and with counter anions such as $[\mathrm{Cl}]^{-},\left[\mathrm{PF}_{6}\right]^{-},\left[\mathrm{BPh}_{4}\right]^{-}$, and $\left[\mathrm{BH}_{4}\right]^{-24,28-30} \mathrm{We}$ have also recently described the $\left[\mathrm{B}\left(\mathrm{C}_{6} \mathrm{~F}_{5}\right)_{4}\right]^{-}$analogue $\left[\mathrm{Rh}\left(\mathrm{PMe}_{3}\right)_{4}\right]\left[\mathrm{B}\left(\mathrm{C}_{6} \mathrm{~F}_{5}\right)_{4}\right]{ }^{31} \mathrm{Rh}(\mathrm{I})$ complexes of this type provide a coordinative and electronically unsaturated metal center which undergo oxidative-addition reactions of relevance to catalysis. Complex $\mathbf{5}$ crystallizes in the space group $P 2_{1}$ with 2 molecules in the unit cell. Fig. 5 shows the overall molecular geometry and atom numbering scheme for $\mathbf{5}$ and a listing of key bond lengths and angles appears in Table 6. The pyrazolate anion is fully dissociated in the solid state with the closest contact between anion and cation of 3.49(2) $\AA$ (F(6)-C (16)). The $\mathrm{Rh}(\mathrm{I})$ center is nearly square planar with the coordination having a slight "butterfly" or "bow-tie" geometry likely due to steric crowding. Both pairs of trans $\mathrm{PMe}_{3}$ groups are
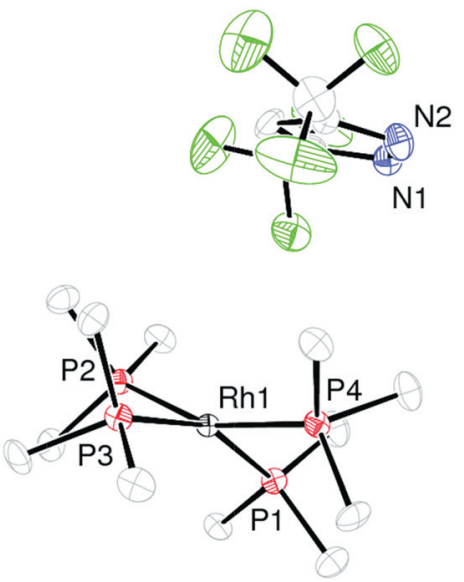

Fig. 5 Molecular structure and atom numbering scheme for [Rh$\left.\left(\mathrm{PMe}_{3}\right)_{4}\right]\left[3,5-\left(\mathrm{CF}_{3}\right)_{2} \mathrm{Pz}\right](5)$. Thermal ellipsoids are scaled to the $30 \%$ probability level. Hydrogen atoms have been omitted for clarity.

Table 6 Selected bond lengths $(\AA)$ and angles $\left(^{\circ}\right)$ for 5

\begin{tabular}{lllc}
\hline Bond lengths & \multicolumn{3}{l}{ Bond angles } \\
\hline $\mathrm{Rh}(1)-\mathrm{P}(3)$ & $2.295(3)$ & $\mathrm{P}(2)-\mathrm{Rh}(1)-\mathrm{P}(1)$ & $91.80(9)$ \\
$\mathrm{Rh}(1)-\mathrm{P}(2)$ & $2.298(3)$ & $\mathrm{P}(3)-\mathrm{Rh}(1)-\mathrm{P}(1)$ & $157.39(10)$ \\
$\mathrm{Rh}(1)-\mathrm{P}(1)$ & $2.299(3)$ & $\mathrm{P}(3)-\mathrm{Rh}(1)-\mathrm{P}(2)$ & $91.57(10)$ \\
$\mathrm{Rh}(1)-\mathrm{P}(4)$ & $2.313(2)$ & $\mathrm{P}(3)-\mathrm{Rh}(1)-\mathrm{P}(4)$ & $92.06(9)$ \\
$\mathrm{P}(1)-\mathrm{Rh}(1)-\mathrm{P}(4)$ & $92.77(10)$ & $\mathrm{P}(2)-\mathrm{Rh}(1)-\mathrm{P}(4)$ & $158.95(10)$ \\
\hline
\end{tabular}

bound so that there is a deviation in the $\mathrm{P}-\mathrm{Rh}-\mathrm{P}$ angle from $180^{\circ}$ (P(1)-Rh-P(3) $\left.157.39(10)^{\circ}, \mathrm{P}(2)-\mathrm{Rh}-\mathrm{P}(2) 158.95(10)^{\circ}\right)$. These deviations are not as severe as those found in [Rh$\left.\left(\mathrm{PMe}_{3}\right)_{4}\right][\mathrm{Cl}]\left(\mathrm{P}-\mathrm{Rh}-\mathrm{P} 147.87(3)^{\circ} \text { av. }\right)^{24}$ The difference is likely due to different packing forces present in the crystals. The average $\mathrm{Rh}-\mathrm{P}$ distance in $\mathbf{5}$ is almost identical to that found in $\left[\mathrm{Rh}\left(\mathrm{PMe}_{3}\right)_{4}\right][\mathrm{Cl}](2.3013(14)$ vs. 2.2970(7) $\AA$ respectively). The $\mathrm{CF}_{3}$ groups were found to possess some rotational disorder and better refinement was achieved through modeling this on one of the groups. The ${ }^{1} \mathrm{H}$ NMR spectrum of 5 in $\mathrm{C}_{6} \mathrm{D}_{6}$ contains a complex multiplet for the $\mathrm{PMe}_{3}$ hydrogens centered at $0.78 \mathrm{ppm}$ while the ${ }^{31} \mathrm{P}\{1 \mathrm{H}\}$ spectrum is a broad singlet centered at $-13.1 \mathrm{ppm}$. The presence of a single peak at $-59.2 \mathrm{ppm}$ in the ${ }^{19} \mathrm{~F}$ NMR spectrum is consistent with the complex existing in the ionic form in solution. Conductivity measurements in $\mathrm{MeCN}$ are also consistent with 5 existing as a 1:1 electrolyte in this solvent.

\section{Film growth and characterization $\uparrow$}

Films were deposited in a horizontal hot-wall CVD reactor using high purity $\mathrm{Ar}$ or $\mathrm{H}_{2}$ as the carrier gas. Using $\mathrm{Ar}$ as the carrier gas at a deposition temperature of $500{ }^{\circ} \mathrm{C}$ for 60 minutes $c a$. $100 \mathrm{mg}$ of precursor 1 gave crystalline rhodium films with thicknesses ranging from 40 to $60 \mathrm{~nm}$ (from SEM). The precursor was heated to $170{ }^{\circ} \mathrm{C}$ and the lines leading to the deposition chamber were held at $175{ }^{\circ} \mathrm{C}$ with a flow rate of $5 \mathrm{sccm}$ and pressure of 0.3 Torr. Deposition temperatures below $400{ }^{\circ} \mathrm{C}$ resulted in much of the precursor passing through the deposition 
Table 7 Film composition using $\mathbf{1}$ and $\mathbf{3}$ and $\mathrm{Ar}$ and $\mathrm{H}_{2}$ as carrier gases

\begin{tabular}{|c|c|c|c|c|c|c|}
\hline Precursor & Carrier gas & Precursor temperature $\left({ }^{\circ} \mathrm{C}\right)$ & Deposition temperature $\left({ }^{\circ} \mathrm{C}\right)$ & \multicolumn{3}{|c|}{ Film composition $(\%)$} \\
\hline 1 & $\mathrm{Ar}$ & 170 & 500 & 15.0 & 78.3 & $\mathrm{n} / \mathrm{a}$ \\
\hline 3 & $\mathrm{Ar}$ & 130 & 350 & 64.0 & 21.0 & 15.0 \\
\hline 3 & $\mathrm{H}_{2}$ & 130 & 350 & 67.0 & 15.0 & 18.0 \\
\hline
\end{tabular}

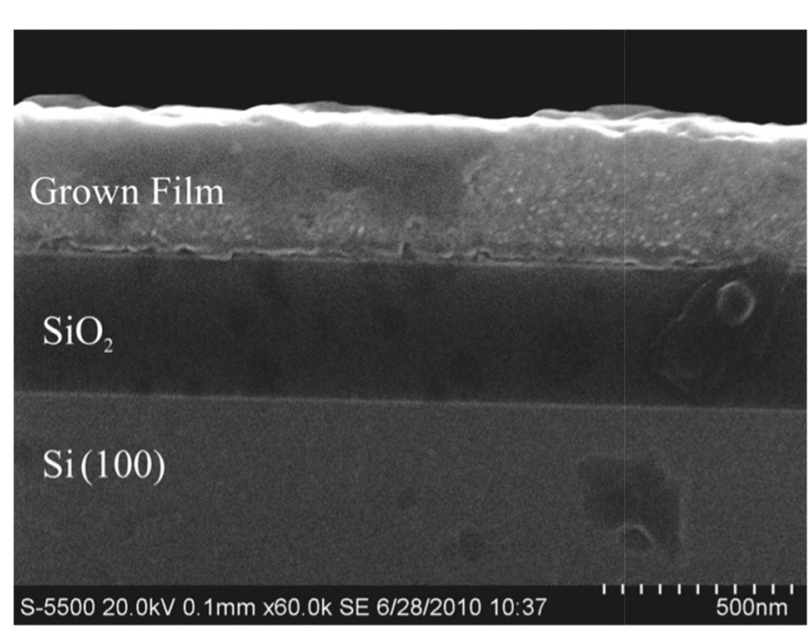

Fig. 6 Side on view of a typical film grown from 3.

chamber intact, while higher temperatures resulted in decomposition of nearly all the precursor. Grazing-incidence XRD revealed only the most intense peaks for fcc-Rh at $40.8^{\circ}$ (111) and $47.45^{\circ}$ (200) $2 \theta^{32}$ XPS analysis revealed mainly $\mathrm{Rh}, \mathrm{O}$, and $\mathrm{C}$ with traces of $\mathrm{F}$ and $\mathrm{N}$ on the surface of the film. Sputtering of the film with ionized argon efficiently removed surface contamination and after 60 seconds of sputtering the only detectable elements were $\mathrm{Rh}$ and $\mathrm{C}$. The quantification of $\mathrm{Rh}$ and $\mathrm{C}$ was carried out using the $\mathrm{Rh} 3 \mathrm{~d}$ doublet and $\mathrm{C} 1 \mathrm{~s}$ peaks. The $\mathrm{C} 1 \mathrm{~s}$ peak was always a single, sharp peak, and the Rh $3 \mathrm{~d}$ doublet did not show any evidence of more than one chemical oxidation state present. After removal of the surface contaminants, the $\mathrm{Rh}$ concentration was determined to be $15 \%$ with $6.7 \%$ nitrogen while carbon comprised the other $78.3 \%$. Further sputtering did not reveal any significant change in concentration within experimental error.

With the exception of the surface contamination, the films were quantitatively homogenous through to the substrate. In the absence of all other impurities save carbon in the bulk material, the relatively high carbon impurities likely come from decomposition of the ethylene at the necessary high deposition temperatures. The metallic silver to pink films were only slightly adhesive to the $\mathrm{SiO}_{2}$ substrate failing both the scratch and tape tests. Other groups have seen dramatic decreases in carbon impurities when $\mathrm{H}_{2}$ is used as the carrier gas. ${ }^{10}$ Films grown using $\mathrm{H}_{2}$ as the carrier gas had significantly less carbon as shown in Table 7. After removal of the surface contaminants, the Rh concentration was determined to be $58.1 \%$ and carbon $41.9 \%$.

The use of $c a .100 \mathrm{mg}$ of precursor 3 with a deposition temperature of $350{ }^{\circ} \mathrm{C}$ for 30 minutes resulted in the deposition of amorphous rhodium phosphide $\left(\mathrm{Rh}_{2} \mathrm{P}\right)$ films with thicknesses of

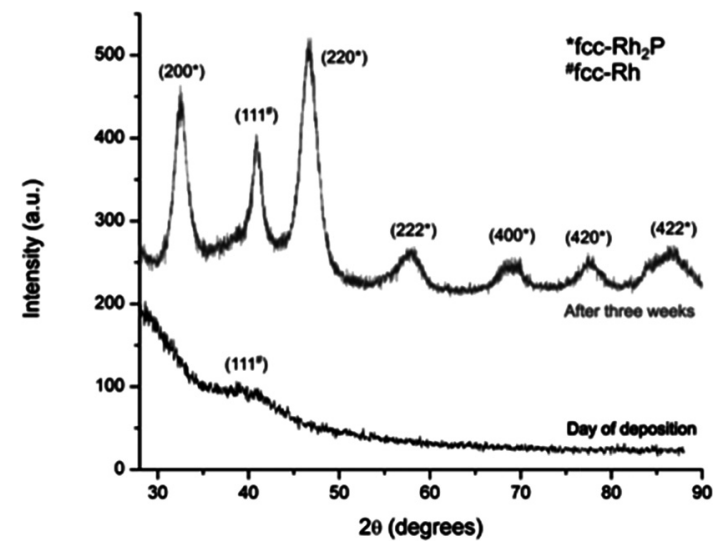

Fig. 7 XRD data: comparison of film grown from 3 at the time of deposition and three weeks later.

150-200 nm (from SEM). The precursor was heated to $130{ }^{\circ} \mathrm{C}$ and the lines leading to the deposition chamber were held at $140{ }^{\circ} \mathrm{C}$ with a flow rate of $5 \mathrm{sccm}$ and pressure of 0.3 Torr. A side on view of a typical film is shown in Fig. 6. Initial grazingincidence XRD revealed only one weak very broad peak corresponding to the most intense peak for rhodium metal at $40.8^{\circ}$ $2 \theta^{32}$ XPS analysis revealed mainly $\mathrm{Rh}, \mathrm{O}, \mathrm{P}$, and $\mathrm{C}$ with traces of $\mathrm{F}$ and $\mathrm{N}$ at the surface of the film. Sputtering of the film with ionized argon efficiently removed surface contamination and after 60 seconds of sputtering the only detectable elements were $\mathrm{Rh}, \mathrm{P}$ and $\mathrm{C}$. The quantification of $\mathrm{Rh}, \mathrm{P}$, and $\mathrm{C}$ were carried out using the Rh $3 \mathrm{~d}$ doublet, $\mathrm{P} 2 \mathrm{p}$ doublet, and $\mathrm{C} 1 \mathrm{~s}$ peaks. The $\mathrm{C} 1 \mathrm{~s}$ peak was always a single, sharp peak, while the Rh $3 d$ and $P 2 p$ doublets did not show any evidence of more than one oxidation state present after the oxide layer was removed. After removal of the surface contaminants, the $\mathrm{Rh}$ concentration was determined to be $64 \%$ with a $\mathrm{P}$ concentration of $15 \%$ while carbon comprised the other $21 \%$. Interestingly, after three weeks of standing under atmospheric conditions, subsequent XRD analysis showed strong peaks corresponding to fcc- $\mathrm{Rh}_{2} \mathrm{P}$ and fcc-Rh metal. ${ }^{32,33}$ A comparison of the two XRD patterns is shown in Fig. 7.

A second amorphous film was grown using $\mathrm{H}_{2}$ as a carrier gas. After removal of the surface contaminants, the $\mathrm{Rh}$ concentration was determined to be $67 \%$ with a $\mathrm{P}$ concentration of $18 \%$ while carbon comprised the other $15 \%$. While a reduction in carbon is achieved by using $\mathrm{H}_{2}$ as the carrier gas it is not entirely removed as shown in Table 7.

We have recently reported RuP amorphous alloys grown utilizing the ruthenium trimethylphosphine complex, cis$\mathrm{RuH}_{2}\left(\mathrm{PMe}_{3}\right)_{4} \cdot{ }^{34}$ The incorporation of phosphorous appears to hinder the formation of crystalline $\mathrm{Ru}$ and similar effect is 
postulated to be taking place here. However, in the case of films grown from 3 at $350{ }^{\circ} \mathrm{C}$ the amorphous material crystallizes after several days at room temperature. When deposition temperatures were raised above $400{ }^{\circ} \mathrm{C}$, the films were found to be crystalline immediately after deposition. Annealing of the amorphous films at $350-450{ }^{\circ} \mathrm{C}$ under vacuum for several hours also produced mixtures of crystalline fcc- $\mathrm{Rh}_{2} \mathrm{P}$ and fcc- $\mathrm{Rh}$. Higher annealing temperatures resulted in a dominance of fcc-Rh with little to no $\mathrm{Rh}_{2} \mathrm{P}$ observed by XRD.

\section{Conclusions}

The synthesis and characterization of a series of rhodium(I) complexes containing the bis-trifluoromethyl-pyrazolate ligand is described. Two of the complexes, $\mathbf{1}$ and $\mathbf{3}$, were shown to be appropriate for use as CVD precursors. 1 deposits fcc-Rh films at deposition temperatures above $500{ }^{\circ} \mathrm{C}$ which are heavily contaminated with carbon. Complex $\mathbf{3}$ is the first pyrazolate complex of the type $\mathrm{Rh}\left(\mathrm{PMe}_{3}\right)_{3} \mathrm{~L}$, and it was shown to be a viable precursor for the deposition of metastable-amorphous $\mathrm{Rh}_{2} \mathrm{P}$ films. The use of $\mathrm{H}_{2}$ as a carrier gas produced amorphous films with less carbon impurities than films grown using Ar.

\section{Experimental}

\section{General procedures}

NMR spectra were recorded at room temperature on either a Varian Unity $300 \mathrm{MHz}$ or Inova $500 \mathrm{MHz}$ spectrometer. Melting points were taken on an Electrothermal instrument in sealed capillaries under 1 atmosphere of $\mathrm{N}_{2}$ or under vacuum at 0.1 Torr $\mathrm{N}_{2}$. IR spectra were obtained on a Nicolet Avatar 330 FTIR spectrometer with a Smart Performer ATR attachment. Mass spectrometry data was collected on a Thermo LTQ Quantum using electrospray ionization in positive mode. Microanalysis performed by Galbraith Laboratories, Inc. Knoxville, TN. All reactions were performed under a dry, oxygen-free nitrogen atmosphere or under vacuum using standard Schlenk line and dry box techniques. All solvents were dried prior to use by distillation from molten sodium or sodium benzophenone ketyl under nitrogen. 3,5-Bis(trifluoromethyl)pyrazole, ${ }^{35}\left[\mathrm{Rh}\left(\mathrm{PMe}_{3}\right)_{2} \mathrm{Cl}\right]_{2},{ }^{36}$ $\left[\mathrm{Rh}\left(\mathrm{PMe}_{3}\right)_{4}\right] \mathrm{Cl}^{37}\left[\mathrm{Rh}(\mathrm{COD})\left(\mu-3,5-\left(\mathrm{CF}_{3}\right)_{2} \mathrm{Pz}\right)\right]_{2}$, and [Rh$\left.\left(\mathrm{C}_{2} \mathrm{H}_{4}\right)_{2} \mathrm{Cl}\right]_{2}{ }^{38}$ were prepared as described in the literature. For the thin film growth studies quantitative elemental characterization was performed using XPS (Kratos AXIS Ultra DLD, monochromatic $\mathrm{Al} \mathrm{K} \alpha$ ). Further film characterization was performed with scanning electron microscopy (SEM) (Zeiss Supra $40 \mathrm{VP})$, and grazing-incident $\left(3^{\circ}\right.$ incident) X-ray diffraction (XRD) (Bruker-Nonius D8 Advance, $\mathrm{Cu} \mathrm{K} \alpha$ ).

$\left[\mathbf{R h}\left(\mathbf{C}_{2} \mathbf{H}_{4}\right)_{2}\left(\mu-3,5-\left(C_{3}\right)_{2} \mathbf{P z}\right)\right]_{2} \quad$ (1). A solution of $\mathrm{n}-\mathrm{BuLi}$ $(1.07 \mathrm{ml}, 1.6 \mathrm{M})$ in $\mathrm{C}_{6} \mathrm{H}_{14}$ was added to a solution of 3,5$\left(\mathrm{CF}_{3}\right)_{2} \mathrm{PzH}(0.35 \mathrm{~g}, 1.72 \mathrm{mmol})$ in $\mathrm{Et}_{2} \mathrm{O}(40 \mathrm{ml})$ at $-78^{\circ} \mathrm{C}$. This solution was stirred for 30 minutes and then warmed to room temperature and stirred for 90 minutes. The solution was then cannulated into a solution of $\left[\mathrm{Rh}\left(\mathrm{C}_{2} \mathrm{H}_{4}\right)_{2} \mathrm{Cl}\right]_{2} \quad(0.334 \mathrm{~g}$, $0.86 \mathrm{mmol}$ ) under an atmosphere on $\mathrm{C}_{2} \mathrm{H}_{4}$ at $-78{ }^{\circ} \mathrm{C}$. The solution was then warmed slowly to room temperature and stirred overnight forming a white precipitate and a bright red solution.
The solution was filtered through a short bed of Celite ${ }^{\circledR}$ and evaporated to dryness. The residue was recrystallized from a hexanes at $-25{ }^{\circ} \mathrm{C}$. Isolated yield: $0.49 \mathrm{~g}, 79 \%$. For 1: m.p. (1 atm $\left.\mathrm{N}_{2}\right) \quad 153-156{ }^{\circ} \mathrm{C}$; (0.1 Torr) $154{ }^{\circ} \mathrm{C}$ sublime. ${ }^{1} \mathrm{H}$ NMR $\left(300 \mathrm{MHz}, \mathrm{C}_{6} \mathrm{D}_{6}, 27^{\circ} \mathrm{C}\right) \delta 6.22(\mathrm{~s}, 1 \mathrm{H}, \mathrm{Ar}-H), 3.22(\mathrm{~m}, 8 \mathrm{H},=$ $\mathrm{CH}), 2.97(\mathrm{~m}, 8 \mathrm{H},=\mathrm{CH}) .{ }^{19} \mathrm{~F}$ NMR $\left(282 \mathrm{MHz}, \mathrm{C}_{6} \mathrm{D}_{6}\right) \delta-58.8$ $\left(\mathrm{s}, \mathrm{CF}_{3}\right) . \mathrm{MS} m / z 565\left[\mathrm{M}^{+}-\mathrm{Rh}\left(\mathrm{C}_{2} \mathrm{H}_{4}\right)_{2}\right], 752\left[\mathrm{M}^{+}+\mathrm{C}_{2} \mathrm{H}_{4}\right]$; FT-IR (ATR, cm ${ }^{-1}$ ): 2962 (w), 2913 (w), 1536 (w), 1511 (w), 1495 (w), 1417 (w), 1344 (w), 1303 (w), 1254 (s), 1205 (w), 1107 (vs), 1017 (m), 1001 (s), 939 (vs), 854 (m), 800 (m). Anal. Found: C, 30.4; H, 2.4; N, 7.9. Calcd: C, 29.8, H, 2.5; N, 7.7\%.

$\left[\mathrm{Rh}_{2}\left(\mathrm{PMe}_{3}\right)_{4}\left(\boldsymbol{\mu}-\mathbf{3 , 5}-\left(\mathrm{CF}_{3}\right)(\boldsymbol{\mu}-\mathrm{Cl})\right]\right.$ (2). A solution of $\mathrm{n}-\mathrm{BuLi}$ $(0.13 \mathrm{ml}, 1.6 \mathrm{M})$ in $\mathrm{C}_{6} \mathrm{H}_{14}$ was added to a solution of 3,5$\left(\mathrm{CF}_{3}\right)_{2} \mathrm{PzH}(0.21 \mathrm{~g}, 1.01 \mathrm{~mol})$ in $\mathrm{Et}_{2} \mathrm{O}(25 \mathrm{ml})$ at $-78{ }^{\circ} \mathrm{C}$. This solution was stirred for 30 minutes and then warmed to room temperature and stirred for 90 minutes. The solution was cannulated into a solution of $\left[\mathrm{Rh}\left(\mathrm{PMe}_{3}\right)_{2} \mathrm{Cl}\right]_{2}(0.587 \mathrm{~g}, 1.01 \mathrm{~mol})$ in $\mathrm{Et}_{2} \mathrm{O}$ at $-78{ }^{\circ} \mathrm{C}$. The resulting reaction mixture was warmed to room temperature and stirred overnight forming a white precipitate. The solution was filtered through a short bed of Celite ${ }^{\circledR}$ and evaporated to dryness. The residue was extracted into hexanes and recrystallized at $-25{ }^{\circ} \mathrm{C}$ to give orange needles. Isolated yield: $0.66 \mathrm{~g}, 87 \%$. For 2: m.p. $\left(1 \mathrm{~atm} \mathrm{~N}_{2}\right) 79-81{ }^{\circ} \mathrm{C}$ (dec.). ${ }^{1} \mathrm{H}$ NMR (300 MHz, $\left.\mathrm{C}_{6} \mathrm{D}_{6}, 27^{\circ} \mathrm{C}\right) \delta 7.04(\mathrm{~s}, 1 \mathrm{H}, \mathrm{Ar}-H), 1.16(\mathrm{~m}$, $\left.36 \mathrm{H}, \mathrm{P}\left(\mathrm{CH}_{3}\right)_{3}\right) .{ }^{19} \mathrm{~F} \mathrm{NMR}\left(282 \mathrm{MHz}, \mathrm{C}_{6} \mathrm{D}_{6}\right) \delta-57.56\left(\mathrm{~d}, J_{\mathrm{F}-\mathrm{P}}=\right.$ $4 \mathrm{~Hz}) ;{ }^{31} \mathrm{P}\{\mathrm{H}\} \mathrm{NMR}\left(243 \mathrm{MHz}, \mathrm{C}_{6} \mathrm{D}_{6}\right) \delta 2.37$ (d, $J_{\mathrm{Rh}-\mathrm{P}}=167$ $\mathrm{Hz}), 2.11\left(\mathrm{~d}, J_{\mathrm{Rh}-\mathrm{P}}=167 \mathrm{~Hz}\right), 1.68\left(\mathrm{dq}, J_{\mathrm{Rh}-\mathrm{P}}=204 \mathrm{~Hz},{ }^{5} J_{\mathrm{P}-\mathrm{F}}=\right.$ $4 \mathrm{~Hz}), 1.416\left(\mathrm{dq}, J_{\mathrm{Rh}-\mathrm{P}}=204 \mathrm{~Hz},{ }^{5} J_{\mathrm{P}-\mathrm{F}}=4 \mathrm{~Hz}\right)$; MS $m / z: 545$ $\left[\mathrm{M}^{+}-\mathrm{Pz}\right], 672\left[\mathrm{M}^{+}-\mathrm{PMe}_{3}\right]$; FT-IR $\left(\mathrm{ATR}, \mathrm{cm}^{-1}\right): 2921(\mathrm{w})$, 1537 (w), 1495 (w), 1371 (w), 1295 (m), 1261 (s), 1213 (m), 1118 (vs), 1018 (m), 945 (vs), 855 (m), 802 (w), 744 (m). Anal. Found: C, 27.1; H,4.8; N, 3.7. Calcd: C, 27.3; H, 5.0; N, 3.7\%.

[Rh( $\left.\left.\mathrm{PMe}_{3}\right)_{\mathbf{3}}\left(\boldsymbol{\mu}-\mathbf{3 , 5}-\left(\mathrm{CF}_{3}\right)_{2} \mathbf{P z}\right)\right]$ (3). A solution of [Rh(COD) $\left.\left(\mu-3,5-\left(\mathrm{CF}_{3}\right)_{2} \mathrm{Pz}\right)\right]_{2}(1.01 \mathrm{~g}, 1.2 \mathrm{mmol})$ in toluene $(75 \mathrm{ml})$ was stirred at room temperature while $\mathrm{PMe}_{3}(0.87 \mathrm{~mL}, 8.45 \mathrm{mmol})$ was added dropwise. The resulting reaction was stirred overnight at room temperature. The solvent was evaporated to dryness under vacuum and the residue was recrystallized in hexanes at $-25{ }^{\circ} \mathrm{C}$ to give yellow needles. For 3: m.p. (1 atm $\mathrm{N}_{2}$ ) 103-105 ${ }^{\circ} \mathrm{C}$; (0.1 Torr) $100{ }^{\circ} \mathrm{C}$ sublime. Isolated yield: $1.14 \mathrm{~g}$, $89 \%$. ${ }^{1} \mathrm{H}$ NMR $\left(300 \mathrm{MHz}, \mathrm{C}_{6} \mathrm{D}_{6}, 27{ }^{\circ} \mathrm{C}\right) \delta 7.01(\mathrm{~s}, 1 \mathrm{H}, \mathrm{Ar}-H)$, $0.89\left(\mathrm{dt}, 9 \mathrm{H}, \mathrm{P}\left(\mathrm{CH}_{3}\right)_{3}\right), 0.73\left(\mathrm{~m}, 18 \mathrm{H}, \mathrm{P}\left(\mathrm{CH}_{3}\right)_{3}\right) .{ }^{19} \mathrm{~F}$ NMR $\left(282 \mathrm{MHz}, \mathrm{C}_{6} \mathrm{D}_{6}\right) \delta-58.5\left(\mathrm{~s}, 3 \mathrm{~F}, \mathrm{CF}_{3}\right),-60.0\left(\mathrm{~s}, 3 \mathrm{~F}, \mathrm{CF}_{3}\right) .{ }^{31} \mathrm{P}$ $\{1 \mathrm{H}\}$ NMR $\left(121 \mathrm{MHz}, \mathrm{C}_{6} \mathrm{D}_{6}\right) \delta-0.51\left(\mathrm{dt}, J_{\mathrm{P}-\mathrm{Rh}}=154.1 \mathrm{~Hz}\right.$, $\left.J_{\mathrm{P}-\mathrm{P}}=47.3 \mathrm{~Hz}, 1 \mathrm{P}\right),-10.21\left(\mathrm{dd}, J_{\mathrm{P}-\mathrm{Rh}}=135.0 \mathrm{~Hz}, J_{\mathrm{P}-\mathrm{P}}=46.5\right.$ Hz, 2P). MS m/z: $331\left[\mathrm{M}^{+}-\mathrm{Pz}\right]$; FT-IR (ATR, $\mathrm{cm}^{-1}$ ): $2962(\mathrm{w})$, 2913 (w), 1536 (w), 1511 (w), 1495 (w), 1417 (w), 1344 (w), 1303 (w), 1254 (s), 1205 (w), 1107 (vs), 1017 (m), 1001 (s), 939 (vs), 854 (m), 800 (m). Anal. Found: C, 30.8; H, 5.1; N, 5.1. Calcd: C, 31.5, H, 5.3; N, 5.2\%.

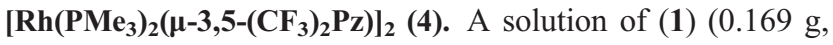
$0.234 \mathrm{mmol})$ in toluene $(40 \mathrm{ml})$ was added to a stirred solution of (3) $(0.5 \mathrm{~g}, 0.936 \mathrm{mmol})$ in toluene $(40 \mathrm{ml})$ under $\mathrm{N}_{2}$. Nitrogen was then bubbled through the solution while stirring for 12 hours. The volume was reduced to $c a .15 \mathrm{ml}$ and the solution cooled to $-25^{\circ} \mathrm{C}$. Yellow crystals formed after $\mathbf{3}$ days. A second isolation from the filtrate produced inferior product. Isolated 
yield: 0.22 g, 34\%. For 4: m.p. (1 atm $\left.\mathrm{N}_{2}\right) 98-100{ }^{\circ} \mathrm{C}$ (dec.). ${ }^{1} \mathrm{H}$ NMR (300 MHz, $\left.\mathrm{C}_{6} \mathrm{D}_{6}, 27{ }^{\circ} \mathrm{C}\right) \delta 6.51(\mathrm{~s}, 2 \mathrm{H}, \mathrm{Ar}-H), 1.07$ (pseudo t, $\left.J_{\mathrm{P}-\mathrm{H}}=3.6 \mathrm{~Hz}, 36 \mathrm{H}, \mathrm{P}\left(\mathrm{CH}_{3}\right)_{3}\right) .{ }^{19} \mathrm{~F} \mathrm{NMR}(282 \mathrm{MHz}$, $\left.\mathrm{C}_{6} \mathrm{D}_{6}\right) \delta-57.97\left(\mathrm{~s}, 12 \mathrm{~F}, \mathrm{CF}_{3}\right) .{ }^{31} \mathrm{P}\{\mathrm{H}\}$ NMR $\left(243 \mathrm{MHz}, \mathrm{C}_{6} \mathrm{D}_{6}\right)$ $\delta 1.62\left(\mathrm{~d}, J_{\mathrm{Rh}-\mathrm{P}}=172.5 \mathrm{~Hz}\right)$. MS m/z: $916\left[\mathrm{M}^{+}\right], 713\left[\mathrm{M}^{+}-\mathrm{Pz}\right]$; FT-IR (ATR, cm ${ }^{-1}$ ): 2962 (w), 2910 (vw), 1417 (w), 1299 (s), 1236 (s), 1150 (s), 1121 (s), 1018 (m), 983 (m), 859 (w), 800 (m), 745 (w), 708 (w). Anal. Found: C, 27.1; H, 4.2; N, 5.7. Calcd: C, 27.8; H, 4.6; N, 6.2\%.

$\left[\mathbf{R h}\left(\mathrm{PMe}_{3}\right)_{4}\right]\left[\mathbf{3 , 5}-\left(\mathrm{CF}_{3}\right)_{2} \mathbf{P z}\right]$ (5). A solution of $\mathrm{n}-\mathrm{BuLi}(1.5 \mathrm{ml}$, $1.6 \mathrm{M})$ in $\mathrm{C}_{6} \mathrm{H}_{14}$ was added to a solution of $3,5-\left(\mathrm{CF}_{3}\right)_{2} \mathrm{PzH}$ $(0.493 \mathrm{~g}, 2.4155 \mathrm{mmol})$ in $\mathrm{Et}_{2} \mathrm{O}(40 \mathrm{ml})$ at $-78{ }^{\circ} \mathrm{C}$. This solution was stirred for 30 minutes and then warmed to room temperature and stirred for 90 minutes. The solution was cannulated into a solution of $\left[\mathrm{Rh}\left(\mathrm{PMe}_{3}\right)_{4}\right] \mathrm{Cl}(0.77 \mathrm{~g}, 2.4155 \mathrm{mmol})$ in $\mathrm{Et}_{2} \mathrm{O}$ $(100 \mathrm{ml})$ at $-78{ }^{\circ} \mathrm{C}$. An additional $0.2 \mathrm{~mL} \mathrm{PMe}_{3}$ was added to the solution. The resulting reaction mixture was warmed to room temperature and stirred overnight forming a white precipitate. The solution was filtered through a short bed of Celite ${ }^{\circledR}$ and evaporated to dryness. The residue was recrystallized from a $\mathrm{C}_{6} \mathrm{H}_{14}$ with an addition $0.2 \mathrm{~mL}$ of $\mathrm{PMe}_{3}$. Orange needles were formed at $-25{ }^{\circ} \mathrm{C}$. For 5: m.p. $120{ }^{\circ} \mathrm{C}\left(1 \mathrm{~atm} \mathrm{~N}_{2}\right) 99-101{ }^{\circ} \mathrm{C}$ sublime to give 4 (0.1 Torr). Isolated yield: $0.94 \mathrm{~g}, 64 \%{ }^{1} \mathrm{H}$ NMR (300 MHz, $\left.\mathrm{C}_{6} \mathrm{D}_{6}, 27{ }^{\circ} \mathrm{C}\right) \delta 7.04(\mathrm{~s}, 1 \mathrm{H}, \mathrm{Ar}-H), 0.78(\mathrm{~m}$, $\left.45 \mathrm{H}, \mathrm{P}\left(\mathrm{CH}_{3}\right)_{3}\right) .{ }^{19} \mathrm{~F} \mathrm{NMR}\left(282 \mathrm{MHz}, \mathrm{C}_{6} \mathrm{D}_{6}\right) \delta-59.2 .{ }^{31} \mathrm{P}\{\mathrm{H}\}$ NMR (121 MHz, $\left.\mathrm{C}_{6} \mathrm{D}_{6}\right) \delta-13.1$ (br s). MS m/z: $407\left[\mathrm{M}^{+}\right], 331$ $\left[\mathrm{M}^{+}-\mathrm{PMe}_{3}\right]$; FT-IR (ATR, cm ${ }^{-1}$ ): 2974 (w), 2908 (w), 1650 (w, br), $1500(\mathrm{w}), 1423(\mathrm{w}), 1329(\mathrm{w}), 1310(\mathrm{w}), 1289(\mathrm{w}), 1242$ (m), 1136 (m), 1105 (s), 1002 (w), 976 (m), 940 (vs), 852 (m), 798 (w), 774 (m), 718 (m); Anal. Found: C, 33.5; H, 5.8; N, 4.8. Calcd: C, 33.5; H, 6.1; N, 4.6.

\section{Single crystal X-ray crystallography}

Crystals were mounted on a glass fiber with Paratone N oil. Data collection was carried out on either a Rigaku Saturn CCD (1-2) or a Bruker-Nonius Kappa CCD (3-5) diffractometer with $\lambda=$ $0.71073 \AA$ using graphite monochromated Mo K $\alpha$ radiation. The structures were solved by direct methods. The coordinates of the non-hydrogen atoms were refined anisotropically, while hydrogen atoms were included in the calculation isotropically but not refined. CCDC reference numbers 858611-858615.† Details of crystal data, data collection, and structure refinements are listed in Table 1.

\section{Acknowledgements}

The authors would like to thank the Welch Foundation (Grant F-816) and the Petroleum Research Fund, administered by the American Chemical Society (47014-ACS) for financial support. X-ray data was collected on instrumentation purchased with funds from NSF grant \# 0741973.

\section{References}

1 M. J. Hampden-Smith and T. T. Kodas, The Chemistry of Metal CVD, 1994.
2 I. K. Igumenov, N. V. Gelfond, N. B. Morozova and H. Nizard, Chem. Vap. Deposition, 2007, 13, 633-637.

3 E. L. Crane, Y. You, R. G. Nuzzo and G. S. Girolami, J. Am. Chem. Soc., 2000, 122, 3422-3435.

4 F. Tian and E. F. Chor, Phys. Status Solidi C, 2008, 5, 1953-1955.

5 H. Lee, R. A. Coutu, S. Mall and K. D. Leedy, J. Micromech. Microeng., 2006, 16, 557-563.

6 G. Hass, J. Opt. Soc. Am., 1982, 72, 27-39.

7 L. Marot, G. De Temmerman, V. Thommen, D. Mathys and P. Oelhafen, Surf. Coat. Technol., 2008, 202, 2837-2843.

8 V. Dal Santo, C. Mondelli, V. De Grandi, A. Gallo, S. Recchia, L. Sordelli and R. Psaro, Appl. Catal., A, 2008, 346, 126-133.

9 F. J. Williams, M. S. Tikhov, A. Palermo, N. Macleod and R. M. Lambert, J. Phys. Chem. B, 2001, 105, 2800-2808.

10 R. Kumar and R. J. Puddephatt, Can. J. Chem., 1991, 69, 108-110.

11 J.-C. Hierso, R. Feurer and P. Kalck, Coord. Chem. Rev., 1998, 178-180, 1811-1834.

12 (a) K. J. Park and G. N. Parsons, Appl. Phys. Lett., 2006, 89, 043111043113; (b) T. Aaltonen, M. Ritala and M. Leskela, Electrochem. SolidState Lett., 2005, 8, C99-C101; (c) J. Hamalainen, F. Munnik, M. Ritala and M. Leskela, J. Electrochem. Soc., 2009, 156, D418-D423; (d) S. D. Elliott, Langmuir, 2010, 26, 9179-9182.

13 (a) Z. Wang, C. D. Abernethy, A. H. Cowley, J. N. Jones, R. A. Jones, C. L. B. Macdonald and L. Zhang, J. Organomet. Chem., 2003, 666, 3542; (b) W. J. McCarty, X-P. Yang, L. J. DePue Anderson and R. A. Jones, Dalton Trans., 2012, 41, 173-179.

14 Y. Chi, H.-L. Yu, W.-L. Ching, C.-S. Liu, Y.-L. Chen, T.-Y. Chou, S.M. Peng and G.-H. Lee, J. Mater. Chem., 2002, 12, 1363-1369.

15 (a) Y. Chi, E. Lay, T.-Y. Chou, Y.-H. Song and A. J. Carty, Chem. Vap. Deposition, 2005, 11, 206-212; (b) O. M. El-Kadri, M. J. Heeg and C. H. Winter, Dalton Trans., 2006, 1943-1953.

16 C. Tejel, J. M. Villoro, M. A. Ciriano, J. A. Lopez, E. Eguizabal, F. J. Lahoz, V. I. Bakhmutov and L. A. Oro, Organometallics, 1996, 15, $2967-2978$.

17 G. A. Ardizzoia, S. Brenna, S. Cenini, G. LaMonica, N. Masciocchi and A. Maspero, J. Mol. Catal. A: Chem., 2003, 204-205, 333-340.

18 L. A. Oro, M. T. Pinillos, A. Tiripicchio and M. Tiripicchio-Camellini, Inorg. Chim. Acta, 1985, 99, L13-L14.

19 C. Tejel, M. A. Ciriano, J. A. López, F. J. Lahoz and L. A. Oro, Angew. Chem., Int. Ed., 1998, 37, 1542-1545.

20 H. Schumann, G. Cielusek, S. Jurgis, E. Hahn, J. Pickardt, J. Blum, Y. Sasson and A. Zoran, Chem. Ber., 1984, 117, 2825-2838.

21 A. M. Arif, R. A. Jones, M. H. Seeberger, B. R. Whittlesey and T. C. Wright, Inorg. Chem., 1986, 25, 3943-3949.

22 B. M. Louie, S. J. Rettig, A. Storr and J. Trotter, Can. J. Chem., 1985, 63, 688-691.

23 G. Aullon, G. Ujaque, A. Lledos, S. Alvarez and P. Alemany, Inorg. Chem., 1998, 37, 804-813.

24 R. A. Jones, F. M. Real, G. Wilkinson, A. M. R. Galas, M. B. Hursthouse and K. M. A. Malik, J. Chem. Soc., Dalton Trans., 1980, 511-518.

25 K. Osakada, K. Hataya and T. Yamamoto, Inorg. Chem., 1993, 32, 2360 2365.

26 S. E. Kegley, C. J. Schaverien, J. H. Freudenberger, R. G. Bergman, S. P. Nolan and C. D. Hoff, J. Am. Chem. Soc., 1987, 109, 6563-6565.

27 B. M. Louie, S. J. Rettig, A. Storr and J. Trotter, Can. J. Chem., 1984, 62, 1057-1067.

28 L. M. Haines, Inorg. Chem., 1971, 10, 1685-1692.

29 K. Burgess, W. A. Van der Donk, S. A. Westcott, T. B. Marder, R. T. Baker and J. C. Calabrese, J. Am. Chem. Soc., 1992, 114, 9350-9359.

30 O. Blum, J. C. Calabrese, F. Frolow and D. Milstein, Inorg. Chim. Acta, 1990, 174, 149-151.

31 J. H. Rivers and R. A. Jones, Chem. Commun., 2010, 46, 4300-4302.

32 J. Häglund, A. Fernández Guillermet, G. Grimvall and M. Körling, Phys. Rev. A, 1993, 48, 11685.

33 M. Zumbusch, Z. Anorg. Allg. Chem., 1940, 243, 322-329.

34 J. Shin, A. Waheed, W. A. Winkenwerder, H.-W. Kim, K. Agapiou, R. A. Jones, G. S. Hwang and J. G. Ekerdt, Thin Solid Films, 2007, 515, $5298-5307$.

35 O. Renn, L. M. Venanzi, A. Marteletti and V. Gramlich, Helv. Chim. Acta, 1995, 78, 993-1000.

36 K. Wang, M. E. Goldman, T. J. Emge and A. S. Goldman, J. Organomet. Chem., 1996, 518, 55-68.

37 R. T. Price, R. A. Andersen and E. L. Muetterties, J. Organomet. Chem., 1989, 376, 407-417.

38 R. J. Angelici, Inorg. Synth., 1990, 28, 86-90. 